\title{
自由落下タンブリング平板の空力特性*
}

平田勝 哉*1, 清 水康介*2, 福 原憲 典*2 山内一 樹*2, 川口大 輔*2, 舟木 治 郎*1

\section{Aerodynamic Characteristics of a Tumbling Plate under Free Flight}

Katsuya HIRATA*3, Kosuke SHIMIZU, Kensuke FUKUHARA, Kazuki YAMAUCHI, Daisuke KAWAGUCHI and Jiro FUNAKI

\footnotetext{
${ }^{* 3}$ Department of Mechanical Engineering, Doshisha University,

1-3 Tataramiyakodani, Kyotanabe-shi, Kyoto, 610-0321 Japan
}

\begin{abstract}
In this study, we deal with the tumbling, which is rotating motion with the axis perpendicular to the falling direction. Our purpose is to reveal the fundamental aerodynamic characteristics of the tumbling, experimentally. Regarding a test plate, we consider a prism with a rectangular cross section with a depth-to-width ratio $\lambda$ of 0.3 . The results are as follows. The reduced terminal rotating rate $\Omega^{*}$, the lift coefficient $C_{L}$, the drag coefficient $C_{D}$ and the lift-to-drag ratio $C_{L} / C_{D}$ are independent of the aspect ratio $A R$, when $A R$ is greater than 10 . As the inertia momen ratio $I^{*}$ increases from zero to $50, \Omega^{*}, C_{L}$ and $C_{D}$ increase. However, $\Omega^{*}, C_{L}$ and $C_{D}$ become almost constant, at $I^{*}$ greater than 50. We propose the empirical formulae to predict them. At low $I^{*}$, the tumbling shows a dominant periodicity of $360 \mathrm{deg}$.
\end{abstract}

Key Words: Autorotation, Flat Plate, Free Flight, Free Fall, Tumbling

\section{1. はじめに}

我々は，日常，木の葉や薄 紙片が空気中を回転しな がら落下するのを，よく目にする，物体は流体中を落下 する際に様々な運動をするが，この例のように，内部動 力源を持たない物体が流体力の作用により持続回転する ことを, オートローテーションと呼ぶ。

オートローテーションには様々なものが知られている

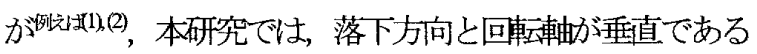
タンブリングを取り扱う。. タンブリングは，木の葉や薄 い紙片の落下運動についての純粋な学問的関心事として のみでなく, 落下したロケット破片の飛散範用の予測な ぞ, 航空宇宙工学や弾道学において重要な現象であり, その現象の解明は工学的にも有益である.

タンブリングについて，これまでに，いくつかの研究 がなされてきた. 1949 年, Dupleich ${ }^{(3)}$ は, アスペクト比 $A R$ が比較的小さい矩形薄板について, 水中と空中での 実験を報告している. 1953年, Smith ${ }^{(4)}$ は，航空機ノーズ のタンブリングの実験を行っている. Bustamante \& Stone ${ }^{(5)}$ は，600-3000[m]の高高度加平板等の自由落下

\footnotetext{
* 原稿受付 2008 年 6 月 26 日.

*1 正員, 同志社大学理工学部 (画610-0321 京田辺市多々羅都 谷 1-3).

*2 同志社大学大学院工学研究科機械工学専攻.

E-mail : khirata@mail.doshisha.ac.jp
}

実験を行い，初期姿勢とはほぼ無関係に平板等がタンブ リングに到るとの知見を得ている．また，亜音速風洞之 超音速風洞でのベアリング支持実験と，圧縮空気銃によ る超音速飛翔実験とを行い，平板および円板，三角板， 円柱がタンブリングすることを確認し，それらの角変位 と角速度を測定している. Smith ${ }^{(6)}$ は，レイノルズ数 $R e=$ $1.3 \times 10^{3}-2.8 \times 10^{5}$ の範用において平板およひ棈円柱につ いて風洞実験を行い，揚力，抗力，回転速度などを測定

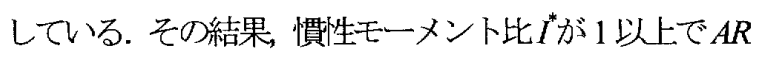

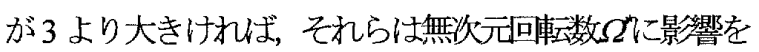

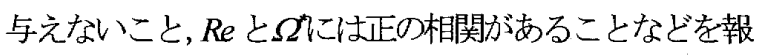
告している. また，回転 1 周期間の各瞬閒での流れ場を 考察し，タンブリングでは失速の遅扎が重要な役割を果 たしていると述へている. Iversen市は，過去の研究者によ る実験結果を比較検討している. 彼は, 研究者間で異な る無次元量を統一し, 各パラメータ間の関係式を整理し ている. そして, Re と $\Omega$ に正の相関が見られるという Smith の結論か澗違っていると指摘している. つまり, ベアリング摩擦により, 見かけ上 $R e$ の増加につれて $\Omega$

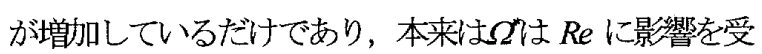
けずに一定值を示すというのが, Iversen の結論である. Poreh\&Wray ${ }^{(8)}$ は，矩形断面平板において, 空中と水中で の自由落下実験を実施し, $\Omega$ や揚力係数 $C_{L}$, 抗力倸数 $C_{D}$ についてのI゙効果と $A R$ 效果を調べている. Yoshinaga et al. ${ }^{(9)}$ は, 位相平面法を用いてトラジェクトリ解析を行い, 
タンブリング物体と気流間のエネルギ一授受関係を議論

している. なお，数值解析によるアプローチも試みられ ており (離散渦法 ${ }^{(10)}{ }^{(11)}$ ，有限差分法 ${ }^{(12)-(14)}$ )，特に流孔 の空間構造の把握に責献している.

上記のようにこれれで，タンブリングに関するいく つかの研究が行われてきた。しかし，末だに，終端状態 でのタンブリング回転数や空気力学特性のような最も基 本的物理量と，支配パラメータとの間の関係すら，充分 に明らかにされていない(後に示す様に，過去の経験式 は，小さい $A R(=025-6.0)$ の結果に基づて近以され ており, 本来2次元現象であるタンブリングに対し現象 の本質的理解を損ないや综，さらに，多くの過去の研 究は，力学状態の規定にあいまいな部分（例えば，Iの みの指定など）を残している）. 基本的物理量の内でも， 特にタンブリング回転数は，周辺の流れ場や空気力に大 きな影響圭及ぼすが，終端状態でのタンブリング回転致 を求めることは，風洞実験 (支持办法等の為) や数值計 算 (剥離流による強非線形性や流れの3 次元性等の為) では, 難しい.

そこで，本研究では，系統立てて規定した力学状態の もと，空気中で自由落下害験を実施し，終端状態こおけ忛 るタンブリング平板の回転数や空力特性を測定する. そ して，それら〜の各種無次元パラメータ個々の影響を独 立して明らかてする.ささらに，水中での自由落下実験に より，運動の詳細を調べる。

\section{2. 記号}

$\begin{array}{lll}A R & : \text { アスペクト比 }(=l / w) & {[-]} \\ C_{D} & : \text { 抗力係数 } & {[-]} \\ C_{L} & : \text { 揚力係数 } & {[-]} \\ d & : \text { 平板厚さ } & {[\mathrm{m}]} \\ D & : \text { 抗力 } & {[\mathrm{N}]} \\ g & : \text { 重力加速度 } & {\left[\mathrm{m} / \mathrm{s}^{2}\right]} \\ I & : \text { 慣性モーメント } & {\left[\mathrm{kg} \cdot \mathrm{m}^{2}\right]} \\ I & : \text { 慣性モ一メント比 } & {[-]} \\ l & : \text { 平板スパン長 } & {[\mathrm{m}]} \\ L & : \text { 揚力 } & {[\mathrm{N}]} \\ n & : \text { 平板の終端回転数 } & {\left[\mathrm{s}^{-1}\right]} \\ R e, R e(V) & : \text { レイノルス数 } & {[-]} \\ t & : \text { 時間 } & {[\mathrm{s}]} \\ U_{\infty} & : \text { 平板並進速度 } & {[\mathrm{m} / \mathrm{s}]} \\ w & : \text { 平板幅 (E代表長さ) } & {[\mathrm{m}]}\end{array}$

: 水平方向座標（タンブリング軸直角方向）

$\begin{array}{lll}y & \text { : 鈆直方向座標 } & {[\mathrm{m}]} \\ z & : \text { 水平方向座標 (タンブリング軸方向) } \\ & & {[\mathrm{m}]} \\ \lambda & : \text { 平板䉼面の縦横比 }(=d w) & {[-]} \\ v & : \text { 動粘度 } & {\left[\mathrm{m}^{2} / \mathrm{s}\right]} \\ \rho_{\mathrm{f}} & : \text { 流体密度 } & {\left[\mathrm{kg} / \mathrm{m}^{3}\right]} \\ \rho_{\mathrm{s}} & : \text { 平板密度 } & {\left[\mathrm{kg}^{3} \mathrm{~m}^{3}\right]}\end{array}$

$\Omega^{*} \quad$ : 無次元終端可転数（終端平板端速度比）

$[-]$

\section{3. 実験方法}

3-1 モデル 図1に, 使用した平板の形状を示 す. 平板の材質は，発泡スチロール，バルサ材，アクリ ル，アルミニウム，銅，鉛であり，材質の違いよより慣 性モーメントIの值を調整している. 平板寸法は，スパ

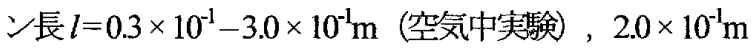

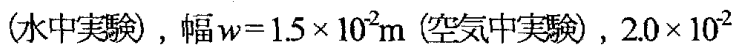
$\mathrm{m}$ (水中実験)，厚さ $d=4.5 \times 10^{-3} \mathrm{~m}$ (空気中実験)，6.0 $\times 10^{-3} \mathrm{~m}$ (水中実験)，アスペクト比 $A R=2-20$ (空気中 実験)，10 (水中実験)，断面繸横比 $\lambda=0.3$ である.

平板端部の処理は，端部での3次元流れに影響を及ぼす ので, 考慮すべき事項の一つである. 本碑では, 特に, 端部に端板を設置する等の処理は行っていないが，後述 する様こ，アスペクト比 $A R$ を充分大きな值 $(A R=20)$ まで考えることにより，アスペクト比效果の検討老行っ ている. なお，予備害験により， $A R=10$ の平板端部に端 板を設置した平板も調べた. しかし，結論から言うと， 端板の有無は，端部の流孔に差異を生じさせ，その解釈 は簡単ではなさそうである.つまり,大きすぎる端板は, タンブリング回転数 $n$ を小さくする効果を持ち，さらに 大きな端板では，タンブリングが発生しにくくなること を確認した.

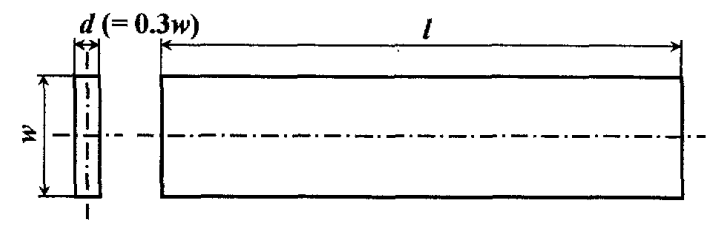

Fig. 1 Tumbling plate; a prism with a rectangular cross section. 
3.2 座標系 図2 に, 座標系を示寸. 水平か タンブリング軸直角方向を $x$ 軸，鉛直方向を $y$ 軸，水平 かかタンブリング軸平行方向を $z$ 軸とする.

3 次元ステレオ撮影を行う際に，カメラの焦点は，予 想される平板落下軌道近くに固定する. 撮影㶦域は，終 端犬態研究対象であるので，なるべく下方が望ましい が，地面効果の影響を避ける為，地表面近くは避ける. 落下前, 軌道付近に 3 次元位置决定の為の透明アクリル 製立方体を設置し，キャリブレーションを実施する.

3・3 パラメータ 支配パラメー夕には形状パラ メータと力学パラメータとがあるが，まず，形状パラメ 一夕を示す. 図10様な平板を考えているので, 形状パ ラメータは，繸横比入とアスペクト比 $A R$ のつである. それらの定義を，以下に示亦。

$$
\begin{aligned}
& \lambda \equiv \frac{d}{w} . \\
& A R \equiv \frac{l}{w} .
\end{aligned}
$$

支配パラメータの内，力学パラメータは，本現象を規 定する為に，2 必要である. 慣例的に，この 2 つの力 学パラメータは，慣性モーメント比 $゙$ とレイノルズ数 $R e$ とすることが多い(例えば, Smith ${ }^{(0)}$. I とReの定義恃， 以下の通りである。

$$
\begin{aligned}
& I^{*} \equiv \frac{32 I}{\pi \rho_{\mathrm{f}} w^{4} l} . \\
& R e \equiv \frac{U_{\infty} w}{v} .
\end{aligned}
$$

ここに，Iは平板慣性モーメントであり，

$$
I \equiv \frac{\rho_{\mathrm{s}} w d l\left(w^{2}+d^{2}\right)}{12}
$$

$\rho_{1}$ は流体密度， $\rho_{3}$ は平板素材密度， $U_{\infty}$ は平板並進速度， い動粘度である.

我々は，Reの代わりに，別のレイノルズ数Re(V)を考 えることもできる. Re(V)の定義を，以下に与える.

$$
\operatorname{Re}(V) \equiv \frac{V w}{v} .
$$

ここに，Vは，理論終端甫度

$$
V \equiv \sqrt{2\left(\frac{\rho_{\mathrm{s}}}{\rho_{\mathrm{f}}}-1\right) w g}
$$

である ${ }^{(13)} . g$ は重力加速度である. 実務的側面加らは， $U_{\infty}$ の代わりに $V$ を使用する利点は自明である. 寸なわち， $V$ の值は事前に与える事ができるが， $U_{\infty}$ の值は実際の計 測を必要とする. $U_{\infty}$ の代わりにVV使用することによる 情報量の垡失は，当然，危惧すべき事項であるが，後に 示可梯に，本実験範用内で確認した所， $V$ と $U_{\infty}$ との対応 関係认近似的に一意に与えることができ，現象の概略の 把握にはVの方がむしろ適している. さらに本論の後半 には，Re(V)代わりにReを用いて，袁失した情報につ いても議論している.

原理的には，2 つの支配力学パラメータの影響を，個 別に評価する必要があるが，自由落下実験に際してバと $\operatorname{Re}(V)$ (あるいは， I"とRe) をその2つとして選ぶと, 各 影響の個別砰価には，技術的困難が生じる. そして，こ の2つの力学パラメータの估別颜価の困難さが，現象の 把屋を混乱させてきた主な原因の1つであった(例えば, Iversenかよ゙でも，ある力学パラメータの影響を評価する 際, もう1つの力学パラメータを同じ值にして比較して いた訳ではない．本研究では，現象の支配パラメータ 依存関係の徹底した解明を考えつつも，上記の困難さを 避ける為，2つの支配力学パラメータの内の 1 つに, 以 下の無次元量を考える.

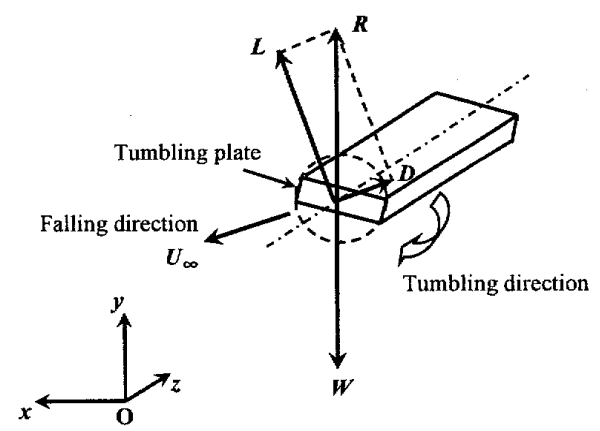

Fig. 2 Schematic diagram of the tumbling rectangular plate and forces. 


$$
C \equiv \frac{\sqrt{g w^{3}}}{v} \text {. }
$$

$C$ は，力学的には(慣性力 $\times$ 重力) $)^{12}$ の粘性力との比に対 忘し，実験では支配パラメータを完全にコントロールすす ることを容易にする，そして，本実験を通して（水中実 験を除く $) ， C$ を定值 $\left(3.86 \times 10^{2}\right)$ に固定し，他の力 学パラメータの影響のみを考える.

2つの力学パラメータのもう1つには、I゙あるいはRe(り) を選ぶ。なお， $C$ と I，Re(V)の関倸は，以下に与えられ る.

$$
\frac{R e(V)}{C}=\sqrt{2\left(\frac{3 \pi}{8} \cdot \frac{I^{*}}{\lambda+\lambda^{3}}-1\right)} .
$$

図3には，本実験 $\left(\lambda=0.3, C=3.86 \times 10^{2}\right)$ での，I゙ $I^{*}$ Re $(V)$ との関係寺示。

本論で考える従属パラメータは，終端快態での，平板 のタンブリング回転数 $n$ と平板の空力特性 (揚力 $L$ と抗 力 $D$ ）である. それらは，それぞれ，無次元回軾数 揚力保数 $C_{L}$ ，抗力倸数 $C_{D}$ として，以下のように定義す る.

$$
\begin{aligned}
& \Omega^{*} \equiv \frac{\pi n w}{U_{\infty}} . \\
& C_{L} \equiv \frac{L}{\frac{1}{2} \rho_{\mathrm{f}} U_{\infty}{ }^{2} w l} . \\
& C_{D} \equiv \frac{D}{\frac{1}{2} \rho_{\mathrm{f}} U_{\infty}{ }^{2} w l} .
\end{aligned}
$$

S'は，定義式(10)からも分かる様に，終端平板端束度比

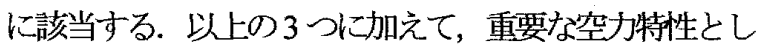
$\tau$, 揚抗比 $C_{L} / C_{D}$ も考元る.

$3 \cdot 4$ 実験装置 空気中実験での装置の概略を図 4 に，水中実験での装置の概略を図 5 に示寸．空気中実 験では, 平板を, 地上約 $7 \mathrm{~m}$ の高さから, 初期回転を与 えて落下させる. 平板落下軌道付近は極力外乱を避けた 状態にし，同期を取った 2 台のハイスピードカメラ(2000 frames/s)によってステレオ撮影を行う．水中実験では， 水深符 $7.5 \times 10^{-1} \mathrm{~m}$ の水槽入平板を自由落下させる. 実験 ごとに充分な時間をとり，水槽内の外乱が減衰した状態 で, 同期した 3 台のハイス゚ードカメラ(500 frames/s)に よってステレオ撮影を行う. 平板の亚進速度 $U_{\infty}$ および $L$, $D$ の測定は，平板圙の中心认設けたマーカの移動距離 を画像解析することにより求める. 平板回車致 $n$ の測定 は，平板側面の中心線上に設けた2点のマ一力を㵋定す ることにより求める.

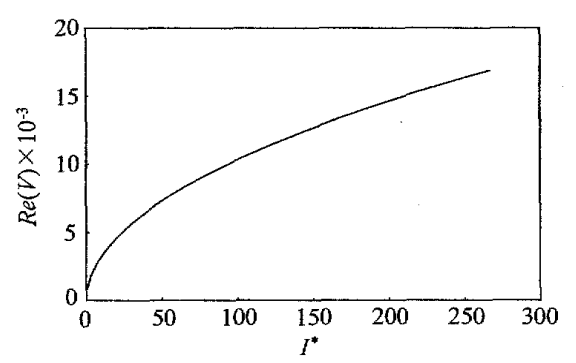

Fig. 3 Relation between inertia-moment ratio $I^{*}$ and Reynolds number $\operatorname{Re}(V)$ based on a theoretical descent velocity $V$ at depth-to-width ratio $\lambda=03, C=3.86 \times 10^{2}$.

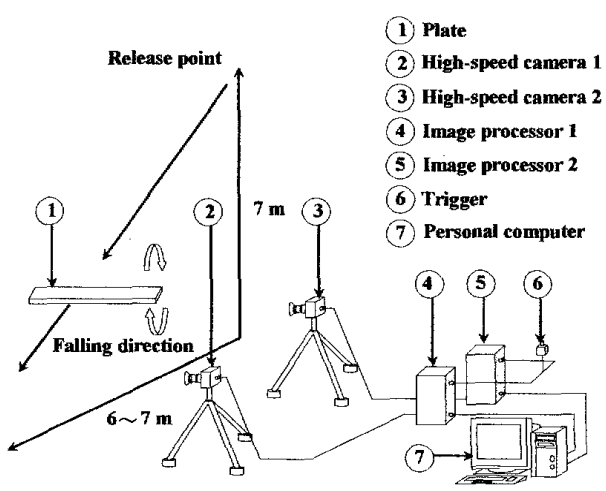

Fig. 4 Experimental apparatus in air.

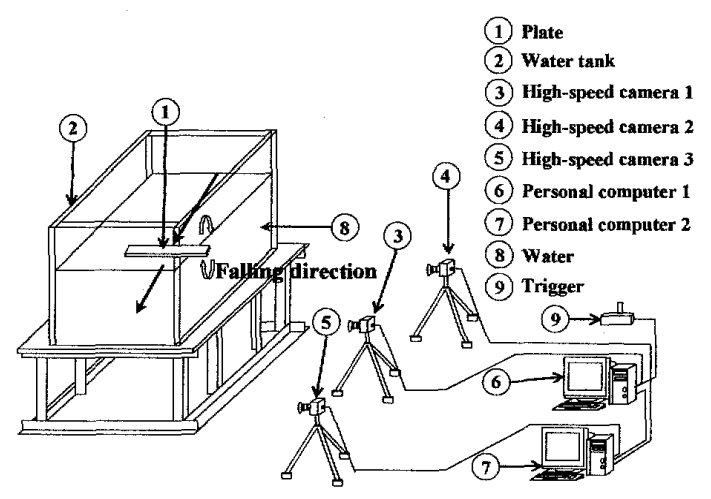

Fig. 5 Experimental apparatus in water. 
Table 1 Symbols and corresponding parameters, in Figs. 7- 10.

\begin{tabular}{c|c|c|c|c|c|c|c} 
Symbol & References & $\lambda$ & $A R$ & $I^{*}$ & $\Omega^{*}$ & $C$ & Experimental method \\
\hline $\mathbf{O}$ & present & 0.3 & $2.0-20$ & 7.73 & $0.27-0.50$ & 380 & free flight \\
\hline 0 & present & 0.3 & $2.0-20$ & 24.4 & $0.15-0.23$ & 380 & free flight \\
\hline$\square$ & $\begin{array}{c}\text { Dupleich } \\
(1949)\end{array}$ & $\begin{array}{c}\text { unknown } \\
(0.003-0.01)\end{array}$ & $1.0-2.5$ & 1.60 & $0.46-0.80$ & 6500 & free flight \\
\hline$\diamond$ & $\begin{array}{c}\text { Dupleich } \\
\text { (1949) }\end{array}$ & $\begin{array}{c}\text { unknown } \\
(0.003-0.01)\end{array}$ & $2.0-2.5$ & 2.70 & $0.53-0.63$ & 3000 & free flight \\
\hline$\Delta$ & $\begin{array}{c}\text { Dupleich } \\
(1949)\end{array}$ & $\begin{array}{c}\text { unknown } \\
(0.003-0.01)\end{array}$ & $2.5-5.0$ & 3.50 & $0.60-0.75$ & 1100 & free flight \\
\hline $\mathbf{\square}$ & $\begin{array}{c}\text { Dupleich } \\
(1949)\end{array}$ & $\begin{array}{c}\text { unknown } \\
(0.003-0.01)\end{array}$ & $2.5-5.0$ & 4.50 & $0.53-0.70$ & 1400 & free flight \\
\hline---- & $\begin{array}{c}\text { Bustamante \& } \\
\text { Stone (1969) }\end{array}$ & $\begin{array}{c}\text { unknown } \\
\text { (thin) }\end{array}$ & $1.7-6.0$ & unknown & Eq. (13) & unknown & wind tunnel \\
\hline & $\begin{array}{c}\text { Iversen (1979) } \\
\text { unknown } \\
(0.0054-0.5)\end{array}$ & $0.25-4.0$ & $\begin{array}{c}\text { more than } \\
\text { about 10 }\end{array}$ & Eq. (14) & unknown & $\begin{array}{c}\text { (Glaser \& Northup, 1971) } \\
\text { free flight } \\
\text { (Bustamante \& Stone, 1969) }\end{array}$
\end{tabular}

\section{4. 結果と考察}

4-1 落下連動の一例 図 6 に撮影結果の一例, すなわち，タンブリング平板の約1回転あたりの運動を 示寸. 矢印は平板䉼面の方向老，点線は平板中心の軌跡 を示寸，平板は，図の右上から左下方向に，時計回りに 回転しながら，落下する. 通常の撮影領域は，図6より も一桁程度広く $(x / w, y / w$ ともに 50 程度 範用 $) ， 3$ 回 軖程度の軌道を充分に視野に納める. 今回は，終端状態 のみを対象としているので，撮影領域内の運動（具体的 には，平板中心の並進速度の 1 周期間平均值）が 3 周期 とも同じであることが確認できた実験結果のみを解析対 象とする.

\section{4-2 アスペクト比 $A R$ の影響タンブリングは,} 回転軸化垂直な面内の二次元的な運動である. Smith $R e=1.3 \times 10^{3}-2.8 \times 10^{5}$ での風洞実験より，ARが 3 より 大きければ， $A R$ はの゙に影響を与えないと述べている. Iversen)は， $A R<4$ の風洞実験結果加ら， $A R$ の増加に伴 いダも増吅することを示している. なお, Smith と Iversen とは共に邠小さい平板を考えており，その点は本研究 $(\lambda=0.3)$ と同じである.

本研究では, $A R=2-20$ の範囲での $A R の \Omega$ と $C_{L}$, $C_{D}, C_{L} / C_{D}$ への影響を調べる. 図7-10に，その結果を まとめる. 詳しく述べると，図7には， $\Omega$ への $A R$ の影 響を示す. 図8-10には，それぞれ， $C_{L}, C_{D}, C_{L} / C_{D}$ へ の $A R$ の影響を示す。. 表1には，図7-10て調查した平 板の各種パラメータ值をまとめる. 各図とも， $I^{*}=7.73$ と 24.4 とで調べている. $\operatorname{Re}(V)=2.83 \times 10^{3}, 5.08 \times 10^{3}$ で あり，結果として, $R e=2.0 \times 10^{3}-3.4 \times 10^{3}$ が調查対象と なる.
図7より， $I^{*}=7.73,24.4$ とも,データのばらつきはあ るが，同し傾向を示すことが分かる. すなおち，AR が

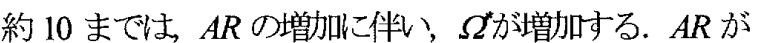
約 10 以上であれば， $\Omega$ は，ほぼ一定值を示し，ほとん

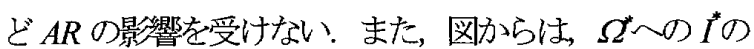
影響が大きいことも分かる。

更に，図7には，他の研究者の結果む示している. 彼 らの各種パラメー夕值も，表1にまとめている. AR の

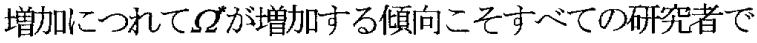
見られるが，定量的には研究者間で大きな隔たりが存在 する.この隔たりは，ARが大きい状態ほど，才なわち， $A R$ 効果が無視できる程度に 2 次元性が良好な状態ほど, 顕著になる. そして, 過去の研究の重大な問題点は, 正 に，この充分に大きな $A R$ で実験結果を欠いているこ とにある (表1 を参照) .

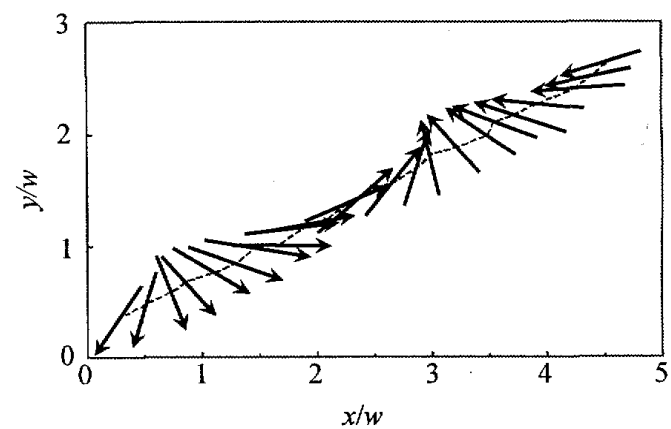

Fig. 6 Locus of a falling plate $\left(\lambda=0.3, A R=10, I^{*}=3.29\right.$, $\left.\operatorname{Re}(V)=1.79 \times 10^{3},\left(\operatorname{Re}=1.8 \times 10^{3}-2.3 \times 10^{3}\right), C=3.86 \times 10^{2}\right)$. Arrows and a dotted line denote the cross-section direction of a plate and the trajectory of a plate's centre, respectively. 
補足として，以下に，この問題点以外の些細な問題点 を指摘する. Dupleich ${ }^{(3)}$ の実験は，各種パラメータ值がよ く管理された条件下で実施されているが，入の值は小さ いが不明である. Bustamante \& Stone $e^{(5)}$ 法，自由落下や風 洞などの様々な実験を実施している．しかし，の゙の経験 式

$$
\Omega^{*}=1-\mathrm{e}^{-0.2 A R}
$$

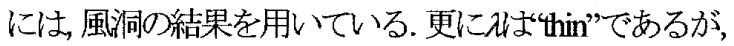

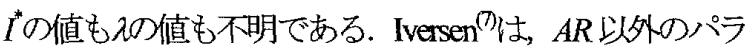
メータについては，広範用のデー夕を用いて次の経験 式頱いている.

$$
\begin{aligned}
& \Omega^{*}=\left(0.329 \ln \lambda^{-1}-0.0246 \ln \lambda^{-1}\right)^{2} \\
& \times\left\{\left[\frac{A R}{2+\left(4+A R^{2}\right)^{\frac{1}{2}}}\right]\left[2-\left(\frac{A R}{A R+0.595}\right)^{0.76}\right]\right\}^{\frac{2}{3}} .
\end{aligned}
$$

しかし，他の研究者の結果を利用している為，パラメー 夕值の独立したコントロールはなされていない．

次に，図8-10を考える! 図8より， $C_{L}$ は， $\Omega$ と同 じ傾向を示すことが分かる.すなわち，ARが 10 までは， $A R$ の増加に伴い， $C_{L}$ が堌加する. $A R$ が 10 以上では， $C_{L} \sim \sigma A R$ の影響は小さい： ${ }^{*}$ の值により， $C_{L}$ の值は大 きく変わる. ただし，データのばらつきは，図7よりも はるが忨さい，図9 は，図7 や図8 と異なる傾向を示 す.すなわち， $C_{D}$ は， $A R$ に影響されず，ほぼ一定值を とる. 図 10 は, 再び, 図8 と同じ傾向を示す.すなおち, $A R \lesssim 10$ で, $A R$ の増加に伴い, $C_{L} / C_{D}$ は増加する. $A R \gtrsim 10$ では， $C_{L} / C_{D}$ は $A R$ によらず, ほぼ一定值を示す。この傾 向は，図 8 と図9の両結果と，上く整合している.ただ し，Iの影響江 2 や $C_{L}, C_{D}$ と異なり，かなり小さい．

以上より, $A R \gtrsim 10$ であ机ば, $S^{\prime や} C_{L}, C_{D}, C_{L} / C_{D}$ へ の $A R$ の影幛ま小さい. よって, 以降は, $A R=10$ の平板 の結果のみを考える.

\section{3 慣性モーメント比「゙の影等 Smith ${ }^{(6)}$ は, $R e=$} $10^{4}$ での自由落下実験に基づき， I゙が 10 以上であれば $C_{L}$ と $C_{L} / C_{D}$ への影響はほとんど無いと述べている. また, Iversen 円はＩ゙が 10 よりも大きければの゙へのI゙の影響は 無いと結論ら゙けている.この結淪に対応する具体的デー 夕は， $\lambda=0.0156$ か $A R=0.5$ のものと思われる. 本研究
では，より広範用の I $\left(10^{0}-10^{2}\right.$ オーダー) を対象と して, $I^{*} か ゙ \Omega^{*}, C_{L}, C_{D}, C_{L} / C_{D}$ 一与える影響を調べる. 寸

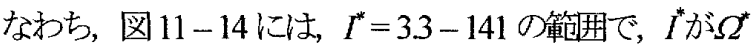
と $C_{L} ， C_{D} ， C_{L} / C_{D}$ 一与える影響を，それぞれ示吉。表 2 には，図中の各シンボルに対応する力学パラメータの值 を示す。なお，䥊線は，図中に記寸近似式に対応してい る.

図11より,データのばらつきはあるが, $I^{*} \lesssim 50$ では,

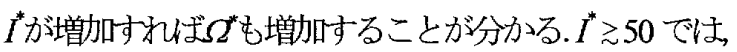
のは、ル゙によらずほぼ一定值をとり，0.4-0.6閒にばらつ く、なお，参考のため，図中に Iversen の経験式 (14) を示している. 彼の結論とは異なり, $I^{*} \approx 10$ では， $I^{*} の$ の゙への影響もまだ大きい：更に，彼の経験式の値も，今 回の結果とは, 大きく異なる.

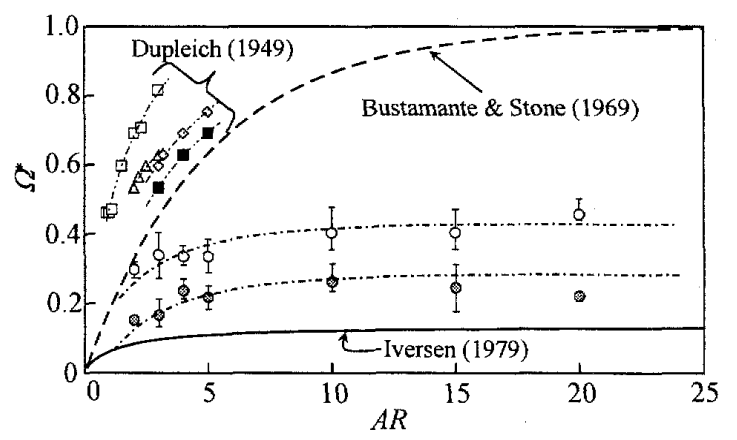

Fig. 7 Reduced rotating rate $\Omega^{*}$ of a tumbling plate versus aspect ratio $A R$ at depth-to-width ratio $\lambda=0.3, C=3.86 \times 10^{2}$.

$I^{*}=7.73, \operatorname{Re}(V)=2.83 \times 10^{3}\left(R e=2.0 \times 10^{3}-2.7 \times 10^{3}\right)$. $P=24.4, \operatorname{Re}(V)=5.08 \times 10^{3}\left(R e=2.6 \times 10^{3}-3.4 \times 10^{3}\right)$.

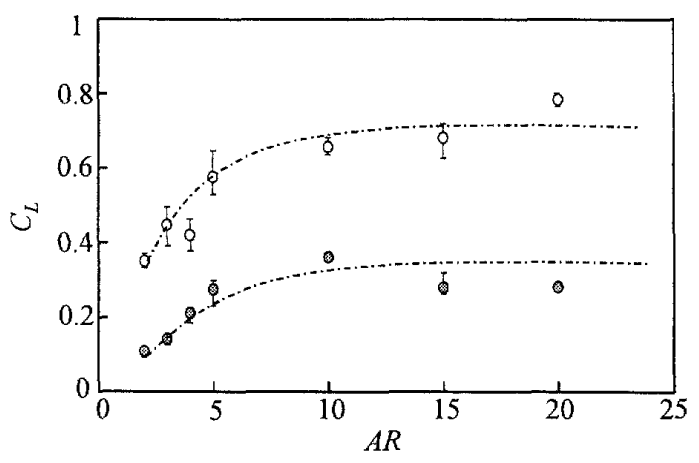

Fig. 8 Lift coefficient $C_{L}$ versus aspect ratio $A R$ at depth-to-width ratio $\lambda=0.3, C=3.86 \times 10^{2}$. $I^{*}=7.73, \operatorname{Re}(V)=2.83 \times 10^{3}\left(\operatorname{Re}=2.0 \times 10^{3}-2.7 \times 10^{3}\right)$ $I^{*}=24.4, \operatorname{Re}(V)=5.08 \times 10^{3}\left(R e=2.6 \times 10^{3}-3.4 \times 10^{3}\right)$. 
Table 2 Symbols and the comesponding $I^{*}, \operatorname{Re}(V)$ and $R e$, in Figs. $11-20\left(\lambda=0.3, A R=10, C=3.86 \times 10^{2}\right)$.

\begin{tabular}{c|c|c|c} 
Symbol & $I^{*}$ & $\operatorname{Re}(V)$ & $\operatorname{Re}$ \\
\hline$\bullet$ & 3.29 & 1790 & $1.8 \times 10^{3}-2.3 \times 10^{3}$ \\
\hline$\circ$ & 7.73 & 2830 & $2.0 \times 10^{3}-2.7 \times 10^{3}$ \\
\hline$\circ$ & 24.4 & 5080 & $2.6 \times 10^{3}-3.4 \times 10^{3}$ \\
\hline$\square$ & 48.7 & 7200 & $3.0 \times 10^{3}-3.8 \times 10^{3}$ \\
\hline$\square$ & 55.9 & 7720 & $3.4 \times 10^{3}-4.2 \times 10^{3}$ \\
\hline$\square$ & 61.9 & 8120 & $3.6 \times 10^{3}-4.6 \times 10^{3}$ \\
\hline$\Delta$ & 65.7 & 8370 & $3.2 \times 10^{3}-3.8 \times 10^{3}$ \\
\hline$\Delta$ & 71.9 & 8760 & $3.7 \times 10^{3}-4.3 \times 10^{3}$ \\
\hline$\Delta$ & 89.5 & 9780 & $4.1 \times 10^{3}-4.7 \times 10^{3}$ \\
\hline$\bullet$ & 103 & 10500 & $4.9 \times 10^{3}-5.1 \times 10^{3}$ \\
\hline$\diamond$ & 108 & 10800 & $5.0 \times 10^{3}-5.9 \times 10^{3}$ \\
\hline$\diamond$ & 120 & 11300 & $5.2 \times 10^{3}-6.2 \times 10^{3}$ \\
\hline$*$ & 141 & 12300 & $4.6 \times 10^{3}-6.4 \times 10^{3}$
\end{tabular}

次に，図 12-14 考える. 図12より，図11 と同様，

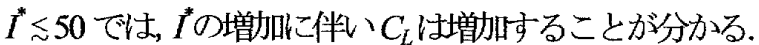
$I^{*} \gtrsim 50$ では，I゙よらず， $C_{L}$ はほぼ一定值 0.9 となる. 図 12 の図 11 との著しい違いは，データのばらつきが小さ いことである. 図 13 より， $C_{D}$ は， $C_{L}$ と定性的にも，定 量的にも同じ傾向を示寸ことが分かる. よって, 図 14 では，その傾向を反映して， $C_{L} / C_{D}$ は， $I^{*}$ の増加につれて 若干の減少傾向惊められるが，゙゙によらずほぼ 1 に近 い值をとる.

なお，図 13 には，Dupleich ${ }^{(3)} の$ 実験值も示しているが， 今回の結果とは定性的にも著しい差異を示しており，今 後のよりパラメータ範用を広げた更なる研究が求められ る. 詳しく述べると， Dupleich ${ }^{(3)}$ の報告では，実験パラメ 一夕の記述が充分でない為, 二種類の方法で, $I$ をを推定 した.すなわち，図中の一印は， $\lambda=0$ と近似したもので ある.ここでは，表1に示したデ一タより多くのデータ を用いた為, $A R$ とCのパラメー夕範用は表 1 より広！ また，図中の十印は，Poreh\& Wray ${ }^{(8)}$ の報告より引用した Dupleich ${ }^{(3)}$ の結果であり，どの原データを使用したか壮不

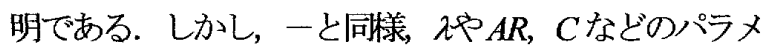
一夕は一定ではないと思われる. よって, 現段皆で, 今 回の実験との乘離を議論することは難しい．

4-4 レイノルス数 $\operatorname{Re}($ (り)影響 前節で, 我々 は，2 つの支配力学パラメータとしで゙と $C$ を考え，C を一定とした条件下で, 緒従属パラメータへの゙の影響 を調べた，その結果， $\Omega$ や $C_{L}, C_{D}$ は，Iのごく簡単な経 験式こより，充分な近似を得られることも示した。

一方, 支配パラメータの選択には任意性があり, 他の 物理量を試みることは，意義がある.ここでは，I゙の代 わりに, Re(りを1つのパラメータに選抧することを考え
る.ここで補足すると，本研究では， $C$ を定としてい るので, 多少のばらつきはあるが, Re と Re(Vの関倸は， ほぼ一意に決まる. 図 15 を参照. なお泪中のシンボル は表2 と共通. )

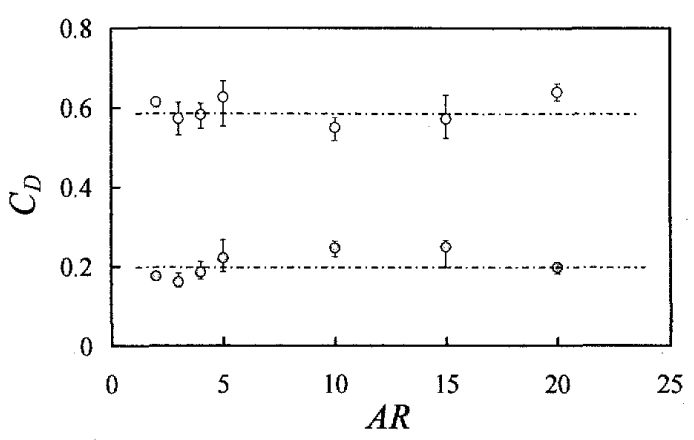

Fig. 9 Drag coefficient $C_{D}$ versus aspect ratio $A R$ at depth-to-width ratio $\lambda=0.3, C=3.86 \times 10^{2}$.

$O I^{*}=7.73, \operatorname{Re}(V)=2.83 \times 10^{3}\left(\operatorname{Re}=2.0 \times 10^{3}-2.7 \times 10^{3}\right)$.

$I^{*}=24.4, \operatorname{Re}(V)=5.08 \times 10^{3}\left(\operatorname{Re}=2.6 \times 10^{3}-3.4 \times 10^{3}\right)$

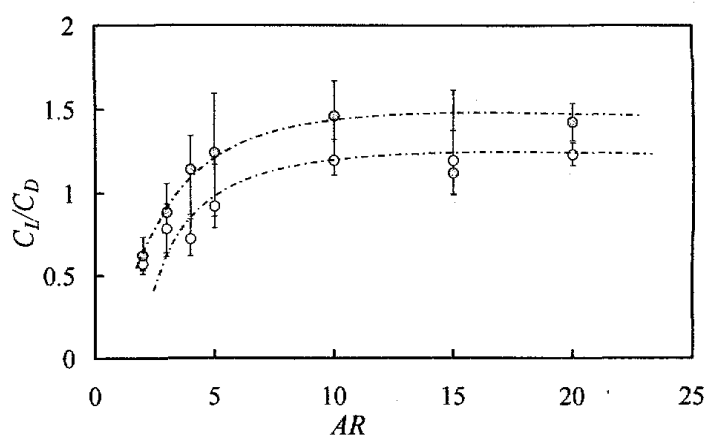

Fig. 10 Lift-to-drag ratio $C_{L} / C_{D}$ versus aspect ratio $A R$ at depth-to-width ratio $\lambda=0.3, C=3.86 \times 10^{2}$.

$I^{*}=7.73, \operatorname{Re}(V)=2.83 \times 10^{3}\left(\operatorname{Re}=2.0 \times 10^{3}-2.7 \times 10^{3}\right)$.

$I^{*}=24.4, \operatorname{Re}(V)=5.08 \times 10^{3}\left(R e=2.6 \times 10^{3}-3.4 \times 10^{3}\right)$ 
Lug( ${ }^{(1)}$ には, データは示されていないが, $R e>1.5 \times 10^{3}$ では，のはほとんどReに依存しないこと，さらに，㤮 小さくかつ $A R$ が大きけれれ゙ $冗 ゙=0.8-1.0$ となるとの記 述がある. Iversen ${ }^{(の)}$, Smith $^{(の)}$ の結果を評価する際， $\Omega$ へのReの影餢が小さいことを前提としている.しかし， これらについての具体的データは示されておらず，定量 的竓論ももちろんない：

図16-19には, $\operatorname{Re}(V)=1.79 \times 10^{3}-1.23 \times 10^{4}$ の範囲で, $\operatorname{Re}(V)$ が $\Omega$ と $C_{L}, C_{D}, C_{I} / C_{D}$ 一与える影響を，それぞれ示 す.なお，図中のシンボルに対応するパラメー夕值は， 再び，表2 と共通である。

図16-18 より, $\operatorname{Re}(V) \leqslant 7 \times 10^{3}$ で, $\operatorname{Re}(V)$ の堌加につれ て, $\Omega^{*}, C_{L}, C_{D}$ は増加することが分かる. $\operatorname{Re}(V) \gtrsim 7 \times 10^{3}$ では， $\Omega^{*}, C_{L}, C_{D}$ とも，ほぼ一定值となる. ただし，デ 一タのばらつきに関しては，片湿著である。また，図 19 には， $C_{L} / C_{D}$ への $\operatorname{Re}(V)$ 影響を示示が，図 17 と図 18 の結果に対応し，Re(V)によらず， $C_{L} / C_{D}$ は1の周りに分 布守る。

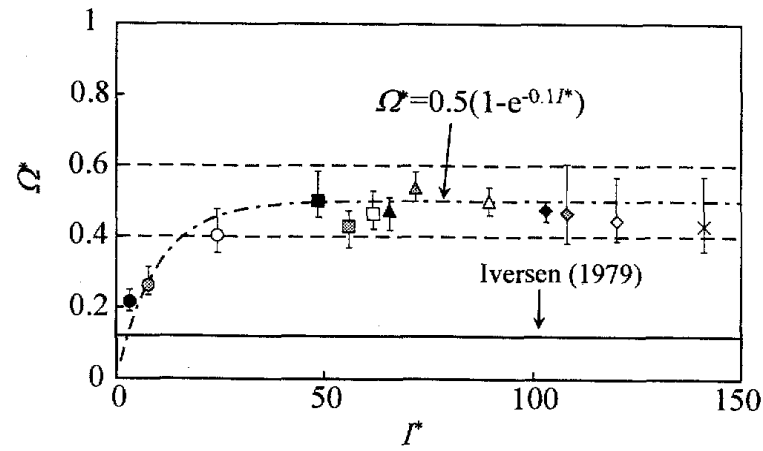

Fig. 11 Reduced rotating rate $\Omega^{*}$ of a tumbling plate versus inertia-moment ratio $I^{*}$, for several values of Reynolds number

$R e$ at depth-to-width ratio $\lambda=0.3$, aspect ratio $A R=10$, $C=3.86 \times 10^{2}$.

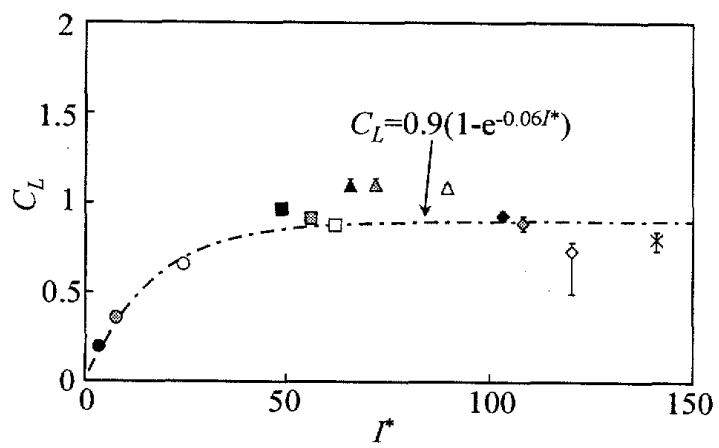

Fig. 12 Lift coefficient $C_{L}$ versus inertia-moment ratio $I^{*}$, for several values of Reynolds number $R e$ at depth-to-width ratio $\lambda$ $=0.3$, aspect ratio $A R=10, C=3.86 \times 10^{2}$.
なお，図16-19には，それぞれ，鎖線で，近似式を描 いている. 図11-14 と同様, 近似式壮, 非常に単純であ るにも関和ず，概ねよい近以を与えている.さらに， 図16-18には，それぞれ，点線で，図11-13中の近似 式も描いている. 図16では，鎖線の方が，近似がより良 好に見え，図17 と図18では，点線の方がより良好に見 える. よって，この結果からは，の゙の予測こは Re(Vの 使用が， $C_{L}$ と $C_{D}$ の予測には I゙の使用が，より適してい るようである.

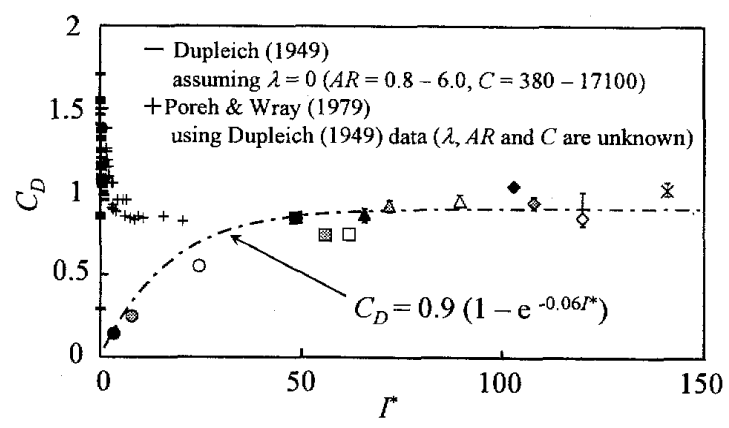

Fig. 13 Drag coefficient $C_{D}$ versus inertia-moment ratio $I^{*}$, for several values of Reynolds number $R e$ at depth-to-width ratio $\lambda$ $=0.3$, aspect ratio $A R=10, C=3.86 \times 10^{2}$.

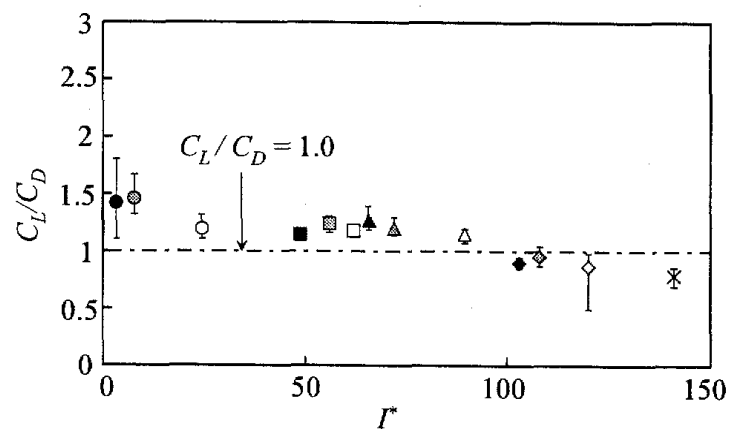

Fig. 14 Lift-to-drag ratio $C_{L} / C_{D}$ versus inertia-moment ratio $I^{*}$, for several values of Reynolds number $R e$ at depth-to-width ratio $\lambda=0.3$, aspect ratio $A R=10, C=3.86 \times 10^{2}$.

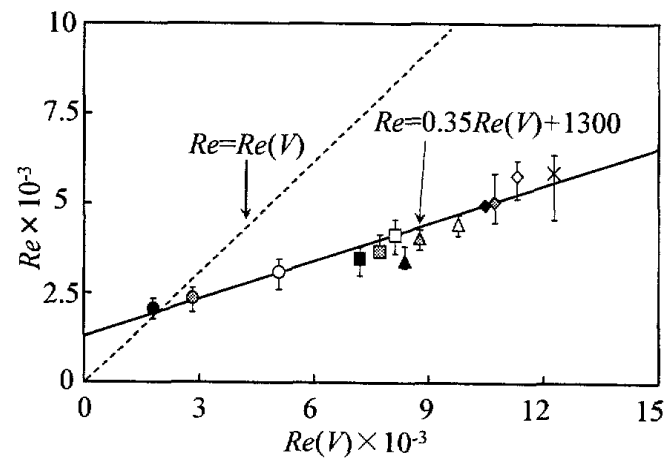

Fig. 15 Reynolds number Re versus Reynolds number $\operatorname{Re}(V)$ based on a theoretical descent velocity $V$, for several values of inertia-moment ratio $I^{*}$ at depth-to-width ratio $\lambda=0.3$, aspect ratio $A R=10, C=3.86 \times 10^{2}$. 
最後に, Reの代わりにRe(Vを用いることにより袁失 する情報を考える. Re と Re(V)との関倸は，概技一意で ある (図 15 を参照)．また，Re(V)効果を考えた時の， $C_{L}$ と $C_{D}$ のデータのばらつきは小さい図 17 と図 18 を 参照) .一方, $\Omega$ は, 同じ $\operatorname{Re}($ (対してデータのばら つきが大きく (図 16 を参照)，情報哀失は $\Omega$ に対して もっとも顕著となる.

ここで補足すると，の゙のばらつきは，条件が終端状態 であるにも拘らず，原データがばらつくことを反映して いる. Andersen et al ${ }^{(13)} /$ ，終端龍態は，初期条件の影響 も強く受けると報告している. 本実験は，彼らと比べ， İ Reもともにかなり大きいので, 彼らの報告に対応す るかどうが断言できないが，先に述べた様に，示した 全てのデー夕は，充分な終端㨢にあることが確認でき たもののみであることも付記しておく。

図20には，Reに対するS゙を示す．結果㤌，図11中あ るい性図 16 中の近似式 図中, 点線で示寸) と概方一致 する. しかし，各でに注目すると，データは，近似式の 周りに，不規郥に分布するのではなく，かなり規斯的に， 1 つ曲線上に落ちる.すなわち, I゙が一定の条件下では, S"はReの増加につれて減少する。

結果から言うと，各 I゙のデータが，同一曲線上に落ち る事実は， $C_{L}$ が $\Omega$ 強く影響を受けていることを反映し ていると思われる，今，自由落下平板の力のつり合いを 考えると，

$$
L^{2}+D^{2}=\left(\rho_{\mathrm{s}} l d w g\right)^{2}
$$

である. Magnus 効果を想定し，

$$
L \propto \rho_{\mathrm{f}} U_{\infty} n w^{2} l .
$$

また，

$$
D \propto \frac{1}{2} \rho_{\mathrm{f}} U_{\infty}^{2} w l .
$$

(15)-(17)式より,

$$
\frac{n^{2} w^{2}}{U_{\infty}^{2}}=\frac{1}{C_{1}^{2}} \frac{g^{2} d^{2}\left(\rho_{\mathrm{s}} / \rho_{\mathrm{f}}\right)^{2}}{U_{\infty}{ }^{4}}-\frac{C_{2}{ }^{2}}{C_{1}^{2}}
$$

を得る.ここに， $C_{1}$ と $C_{2}$ は，それぞれ，式(10)と(17)に 対応する比例乗数である. 次に

$$
\begin{aligned}
& \frac{1}{C_{1}}=\frac{64 v^{2}\left(1+d^{2} / w^{2}\right)^{2}}{9 \pi^{4} g^{2} w^{6}} A, \\
& \frac{C_{2}{ }^{2}}{C_{1}{ }^{2}}=\frac{1}{\pi^{2}} B
\end{aligned}
$$

と置き，式(3)-(5)，(10)を用いて無次元化して，

$$
\Omega^{*}=\sqrt{A \frac{I^{* 2}}{R e^{4}}-B}
$$

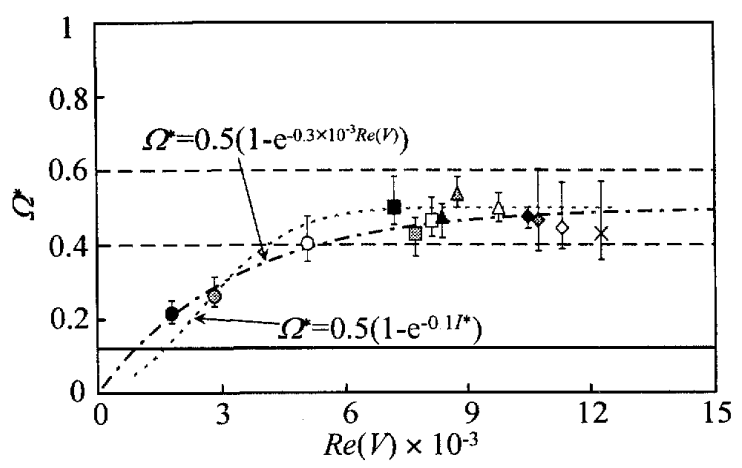

Fig. 16 Reduced rotating rate $\Omega^{*}$ of a tumbling plate versus Reynolds number $\operatorname{Re}(V)$ based on a theoretical descent velocity $V$, for several values of inertia-moment ratio $I^{*}$ at depth-to-width ratio $\lambda=0.3$, aspect ratio $A R=10, C=3.86 \times 10^{2}$.

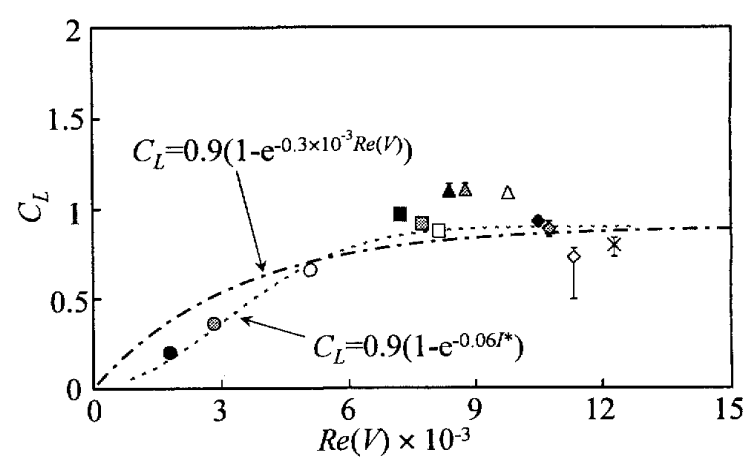

Fig. 17 Lift coefficient $C_{L}$ versus Reynolds number $\operatorname{Re}(V)$ based on a theoretical descent velocity $V$, for several values of inertia-moment ratio $I^{*}$ at depth-to-width ratio $\lambda=0.3$, aspect ratio $A R=10, C=3.86 \times 10^{2}$. 
を得る. $A, B$ を実験値より与えて，描写したものが図中 の鎖線であり，それらと実験㒹はよい対応を示す。

なお，式(21)に，図 15 の近似した ReとRe(V)との関係 を用いると, 我々は, $R e$ と $\Omega$ との関係を得, 更に, I゙あ

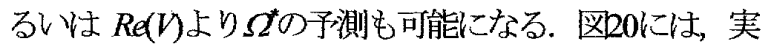
線で, その関倸式を描く. 残念ながら, 他の近似式と比 べると，若下，その精度は劣るようである.

\section{5 タンブリングの樾周期 図 21 と22に,} 水中を自由落下タンブリングする $I^{*}=2.5$ と 0.75 の平板 の約3 回転分の角速度変動の結果老，それぞれ示す，い ずれの図も，縦軸は角速度 $\omega$ を平均角速度 $\omega_{\text {ave }}(=2 \pi n)$ で無次元化した值であり，横軸沋時間 $t$ を回転数 $n$ て無 次元化した值である. なお゙, 本節の水中実験では, $C=8.86$ $\times 10^{3}$ である.

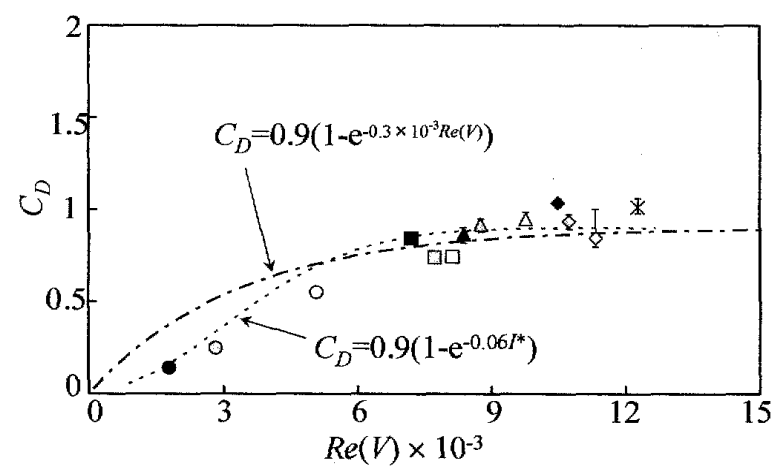

Fig. 18 Drag coefficient $C_{D}$ versus Reynolds number $\operatorname{Re}(V)$ based on a theoretical descent velocity $V$, for several values of inertia-moment ratio $I^{*}$ at depth-to-width ratio $\lambda=0.3$, aspect ratio $A R=10, C=3.86 \times 10^{2}$.

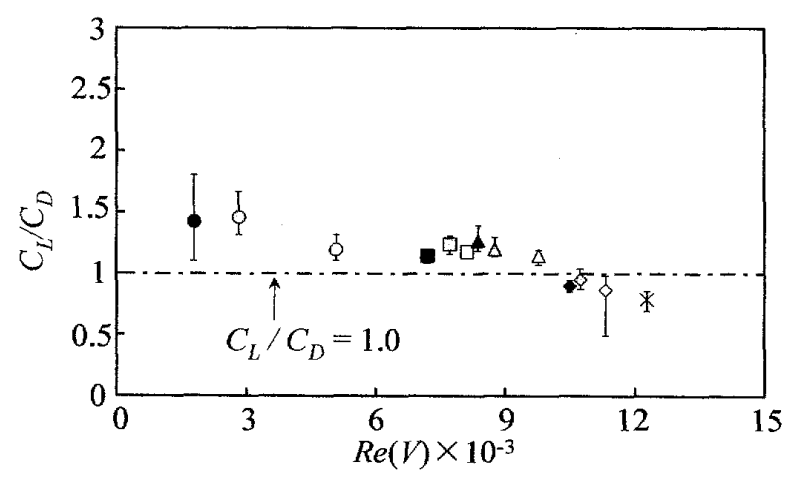

Fig. 19 Lift-to-drag ratio $C_{L} / C_{D}$ versus Reynolds number $\operatorname{Re}(V)$ based on a theoretical descent velocity $V$, for several values of inertia-moment ratio $I^{*}$ at depth-to-width ratio $\lambda=0.3$, aspect ratio $A R=10, C=3.86 \times 10^{2}$.
まず, 図 21 では, $180^{\circ}$ (半回転すなわち $n=0.5$ ) の周 期性が卓越する典型的なタンブリングを，確認できる。 すなわち，平板が 3 回転する間に， 6 回の明膫な周期変 動が現れる. しかし，図をよく見ると，180周期の卓越 成分の他に $360^{\circ}$ （一回転すなわち $\mathrm{n}=1$ 1) 周期の成分も 見られる. 例えば, $\omega \omega_{\mathrm{are}}$ のピーク值は, 約 1.3 のものと 約 1.1 のものとが交互に一回車ごとに現れている.

この $360^{\circ}$ の周期性は, 図 22 では, 更に顕著になる. 他の案験加㤬，「が減少すると，たとえReが大きくて も, 半回転で 1 変動の周期性 ( $180^{\circ}$ の周期性) の他に, 1 回転で 1 変動の周期性（360\%の周期性）の卓越成分も顕 著になることも観察した．図23には，図22 と同条件下 での平板の軌道と姿勢基に示しているが，2 つの卓越 周期成分法，軌跡加も認められる．つまり，半回軽間 に長距離移動する区間と半回転に短距離移動する区間と が交互に現れている。

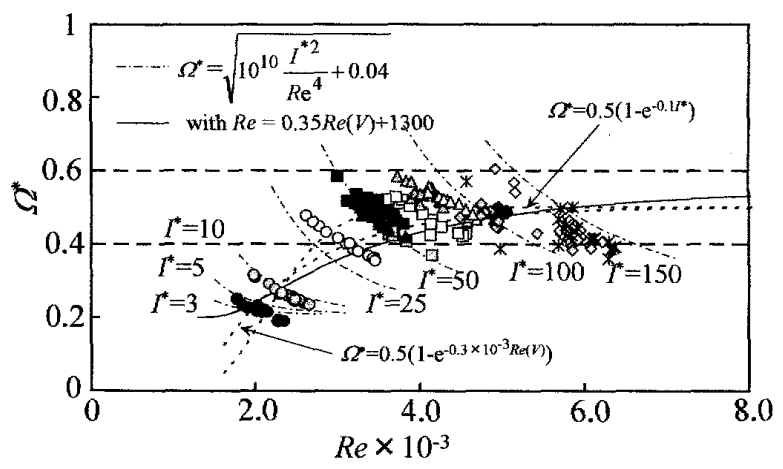

Fig. 20 Reduced rotating rate $\Omega^{*}$ of a tumbling plate versus Reynolds number $R e$, for several values of inertia-moment ratio $I^{*}$ at depth-to-width ratio $\lambda=0.3$, aspect ratio $A R=10$, $C=3.86 \times 10^{2}$.

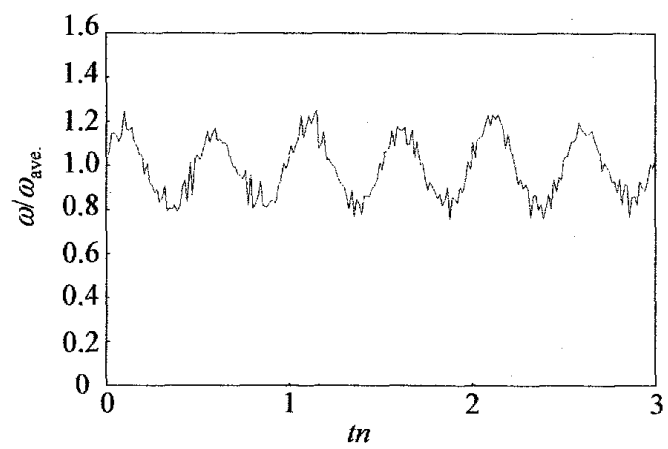

Fig. 21 Dimensionless angular velocity $\omega^{\prime} \omega_{\text {awe }}$ of rectangular plate versus reduced time $m$ for inertia-moment ratio $I^{*}=2.5$, $\operatorname{Re}(V)=3.54 \times 10^{4}\left(\operatorname{Re}=1.4 \times 10^{3}-1.6 \times 10^{3}\right)$, at depth-to-width ratio $\lambda=0.3$, aspect ratio $A R=10$. 
Smith ${ }^{(0)}$ はンブリング回軽の 1 周期が $180^{\circ}$ と述べてお り，その後の研究者の解釈も同一である. これはタンブ リング平板が対称断面形状であることを考えると自然に 思われる. しかし，図22 に示す様に，1周期が $180^{\circ}$ の現 象に加えて，1 周期が $360^{\circ}$ 現象も卓越することもある (例えば, Andersen et al ${ }^{(13)}$ ) ．著者らは，風洞実験にお いてもこの現象を観察している. そこでは，Reが大き くても，I゙が小さければ,この $360^{\circ}$ 周期の現象か顕著に なりがちな傾向を示すので, Andersen et al,の様なカオス に見られる周期吪との単純な同一視は難しいかもしれ ない!

\section{5. おわりに}

空気中でタンブリング平板の自由落下実験を行つた。 実験条件は， $\lambda=0.3 ， A R=2-20, I^{*}=3.3-141$ である. 実験を通して一方の力学パラメータ $C=3.86 \times 10^{2}$ と固定 して，他の力学パラメータの純粋な影響を調べた，結果 を以下にまとめる.

(1) $A R \gtrsim 10$ であれば, $\Omega$ $, C_{L}, C_{D}, C_{L} / C_{D} \sim 9 R$ の 影䛲は小さい!

(2) $I^{*} \gtrsim 50$ 以上であれば, $\Omega^{*}, C_{L}, C_{D}, C_{L} / C_{D} \sim の I^{*}$ の 影響さ小さい．

(3) $\operatorname{Re}(V) \gtrsim 7 \times 10^{3}$ であれば, $\Omega, C_{L}, C_{D}, C_{L} / C_{D} \sim の$ $\operatorname{Re}(V) \sigma$ 影䇾さ小さい!

(4) $\Omega^{*}, C_{L}, C_{D}, C_{L} / C_{D}$ の経験式を提案した.

(5) $\operatorname{Re}$ の代わりに $\operatorname{Re}(V)$ 考えることにより裚失する情 報については，Lが Magnus 効果にほぼ支配されて いると見なし，説明できることを示した。

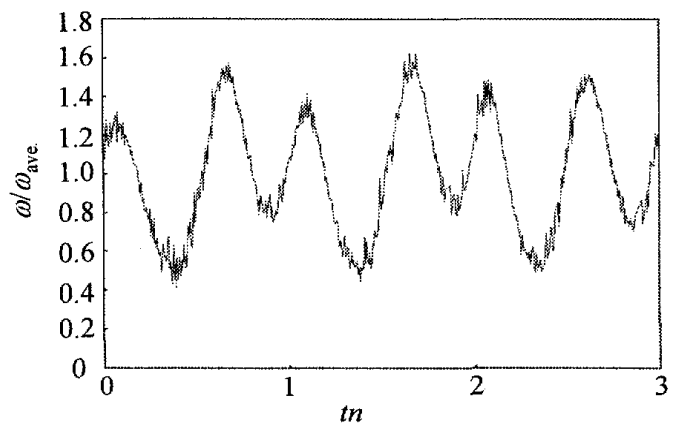

Fig. 22 Dimensionless angular velocity $\omega^{\prime} \omega_{\text {ave }}$ of rectangular plate versus reduced time $t n$ for inertia-moment ratio $I^{*}=0.75$, $\operatorname{Re}(V)=1.63 \times 10^{4}\left(\operatorname{Re}=7.1 \times 10^{3}-7.7 \times 10^{3}\right)$, at depth-to-width ratio $\lambda=0.3$, aspect ratio $A R=10$.
以上の結果は，2つの支配力学パラメータが完全にコ ントロールされた実験に基づくものであり，今回調べた パラメー夕範井内では, 得られた結論の信頼性は高い! 一方で，Cの影響を明らかれするなど，試験範用を広げ ることにより，過去の研究結果との整合性や，より広い パラメータ範囲での精度の高いタンブリング予測などが 期待できよう。

更に，水中実験により，運動を解析した．その結果， I゙が小さくなるほど，タンブリングは，180周期の卓越成 分の他に， $360^{\circ}$ 周期の卓越成分が顕著になることを確認 した.

\section{謝辞}

本研究は，一部，文部科学省学術フロンティア推進事 業「次世代ゼロエミッション・エネルギー変換システム] の支援を受けた。

\section{文献}

(1) H. J.Lugt, Autorotation, Annual Review of Fhid Mechanics, 15, 1983,pp.123-147.

(2) T. Yoshinaga and A.Tate, Autorotation of slender bodies, Transactions of Japanese Society for Aeronautical and Space Sciences, 33, 1985, pp. 367-373 (in Japanese).

(3) P. Dupleich, Rotation in free fall of rectangular wings of elongated shape, NACA Technical Memorandum, 1201, 1949, pp. 1 - 99 .

(4) A.M. O. Smith, On the motion of a tumbling body, Journal of The Aeronautical Sciences, 20, 1953, pp.73-84.

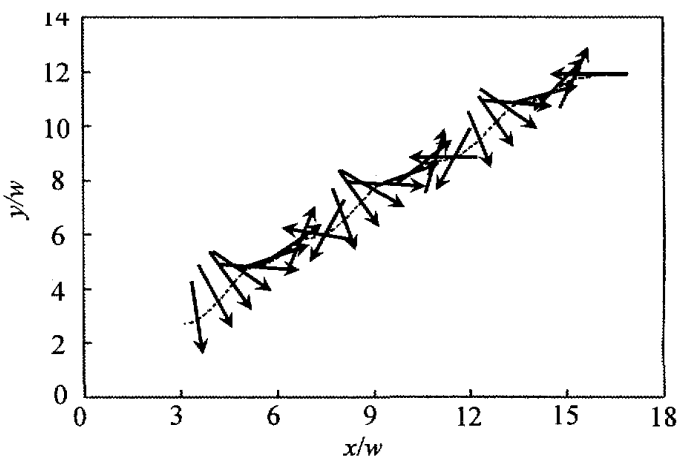

Fig. 23 Locus of a falling plate $\left(\lambda=0.3, A R=10, I^{*}=0.75\right.$, $\left.\operatorname{Re}(V)=1.63 \times 10^{4},\left(\operatorname{Re}=7.1 \times 10^{3}-7.7 \times 10^{3}\right)\right)$. Arrows and $\mathrm{a}$ dotted line denote the cross-section direction of a plate and the trajectory of a plate's centre, respectively. 
(5) A. C. Bustamante and G. W. Stone, The autorotation characteristics of various shapes for subsonic and hypersonic flows, AIAA Paper., 1969, No.69-132.

(6) E.H. Smith, Autorotating wings, an experimental investigation, J. Fhid Mech, 50, 1971, pp.513-534.

(7) J. D. Iversen, Autorotating flat-plate wings, the effect of the moment of inertia, geometry and Reynolds number, J. Fhid Mech., 92, 1979, pp.327-348.

(8) M. Porch and R. N. Wray, On the motion of rectangular prismatic bodies, Journal of Fluids Engineering, 101, 1979, pp. 193-199.

(9) T. Yoshinaga, K. Inoue and A. Tate, Determination of the pitching characteristics of tumbling bodies by the free-rotation method, Joumal of Spacecraft and Rockets, 21, No. 1, 1984, pp. $21-28$.

(10) Y. Ishida, A Numerical Study of flow past a rotating flat plate by the discrete vortex method, Transactions of Japanese Society for Aeronantical and Space Sciences, 25, 1982, pp. 114-125.

(11) Y. Oshima, N. Izutsu, K. Oshima and K. Kuwahara, Autorotation of elliptic airfoil, ALAA Paper, 83 - 0130, 1983, pp. 1-8.

(12) H. J. Lugt, Autorotation of an elliptic cylinder about an axis perpendicular to the flow, J. Fhid Mech, 99, 1980, pp. 817 840.

(13) A. Andersen, U. Pesavento and Z. J. Wang, Unsteady aerodynamics of fluttering and tumbling plates, J. Fhid Mech, 541, 2005, pp. 65-90.

(14) T. Yasuda and Y. Takano, Studies of flow pattem and fluid dynamic forces around an rotating elliptic cylinder (1st report, comparison between wind-tunnel experiment and numerical analysis based on finite volume method), Transactions of Jopanese Society of Mechanical Engineers, Series B, 72, No. 718, 2006, pp. 1404-1409 (in Japanese). 